\title{
Meningkatkan Motivasi dan Prestasi Belajar Sejarah dengan Metode Cerita Bergambar pada Siswa Kelas XI SMA Negeri 1 Blitar
}

\author{
Khotijah Andayani ${ }^{(1)}$ \\ ${ }^{1}$ SMAN 1 Blitar \\ Email: ${ }^{1}$ khotijahandayani@yahool.com, \\ DOI: https://doi.org/10.28926/riset_konseptual.v2i2.46
}

\begin{abstract}
ABSTRAK
Pada mata pelajaran Sejarah khususnya di SMA dimana motivasi belajar sejarah masih tergolong rendah yang berakibat pada rendahnya prestasi belajar siswa. Sebagai guru sejarah, peneliti mencoba mempraktekkan metode Cerita Bergambar dengan jalan memberikan tugas kepada siswa untuk menuangkan tema dalam bentuk Cerita Bergambar dan mempresentasikannya di depan kelas. Penggunaan metode ini ternyata dapat menghasilkan hal-hal positif bagi siswa antara lain : daya pikir dan kreativitas siswa bertambah; motivasi siswa dalam belajar meningkat terbukti dalam melihat dan menanggapi cerita bergambar yang dipresentasikan banyak yang aktif; prestasi belajar bertambah bagus dari hasil ulangan harian;dan tidak lagi dijumpai anak yang malas atau tidur ketika pembelajaran berlangsung.
\end{abstract}

Kata kunci: sejarah, motivasi belajar, cerita bergambar,

\section{PENDAHULUAN}

Pembelajaran merupakan suatu proses tingkah laku yang diperoleh melalui pengalaman individu yang bersangkutan. Dalam proses pembelajaran tidak hanya melibatkan fakta atau konsep sesuatu bidang ilmu saja tetapi juga melibatkan perasaan- perasaan yang berkaitan dengan emosi, kasih sayang, benci, hasrat dengki dan kerohanian. Pembelajaran tidak terbatas pada apa yang kita reancanakan saja tetapi juga melibatkan pengalaman yang di luar kesadaran penuh kita, seperti peristiwa kemalangan atau seorang yang jatuh cinta pada pandangan pertama ( Asrori, $\mathrm{H}$. Moh,2007:6 )

Pembelajaran merupakan suatu kegiatan yang melibatkan seseorang dalam upaya memperoleh pengetahuan, ketrampilan, nilai-nilai positif dengan memanfaatkan sumber-sumber belajar. Pembelajaran dapat melibatkan dua pihak yaitu siswa sebagai pembelajar dan guru sebagai fasilitator. Yang terpenting dalam kegiatan pembelajaran adalah terjadinya proses belajar ( Susilana,Rudi. 2007:1)

Pada pembelajaran Sejarah, motivasi siswa untuk belajar masih rendah. Ini dibuktikan ketika mereka diberi pertanyaan di awal pelajaran banyak yang tidak menjawab, disaat dijelaskan materi banyak yang tidak memperhatikan bahkan berbicara sendiri. Keadaan ini tentu membuat prihatin sehingga perlu mencari jalan pemecahannya agar tidak berlarut-larut yang nantinya bisa mempengaruhi prestasi belajar siswa.

Pembelajaran akan berlangsung dengan baik jika didukung oleh kondisi lingkungan belajar yang kondusif. Pembelajaran atau pengajaran pada dasarnya merupakan kegiatan guru menciptakan situasi agar peserta didik belajar. Tujuan utama dari pembelajaran ini adalah agar peserta didik belajar (Sukmadinata, 2004: 149). Jika metode pembelajaran yang digunakan tidak menyenangkan bagi siswa, maka memungkinkan suasana di kelas menjadi tegang dan siswa tidak akan tertarik dalam belajar Sejarah. Selain itu siswa tidak akan merasa senang dan nyaman dalam mengikuti pembelajaran. Pembelajaran yang tidak diikuti oleh rasa menyenangkan bagi anak, akan mengakibatkan perasaan terpaksa bagi anak dalam mengikuti pelajaran. Salah satu contoh pembelajaran yang menyenangkan bagi anak adalah 
pembelajaran dengan suasana bermain tapi serius. Oleh karena itu, sangat penting pembelajaran Sejarah dengan suasana santai, bermakna, dan menyenangkan bagi siswa.

Motivasi merupakan dorongan yang muncul baik di dalam siswa atau guru maupun dari luar melakukan sesuatu (Rasyid, Harun dkk, 2007 : 39 ). Motivasi berkaitan erat dengan tujuan yang ingin dicapai oleh siswa berupa tujuan pembelajaran. Dari tujuan pembelajaran ini dapat dilihat hasil prestasi belajar siswa. Motivasi belajar adalah sesuatu yang mendorong siswa untuk berprilaku yang langsung menyebabkan munculnya prilaku dalam belajar. Siswa akan melakukan suatu proses belajar betapapun beratnya jika ia mempunyai motivasi tinggi. Tanpa motivasi belajar siswa tidak dapat belajar. Siswa sudah tahu apa yang diinginkan, sudah mempunyai cita - cita, menemukan apa yang diminati. Yang ingin mendapatkan nilai prestasi belajar yang baik dan segera menyelesaikan pendidikannya. Ini dapat menimbulkan motivasi belajar.( Sumiati, dkk, 2007 : 59 )

Prestasi belajar adalah kecakapan nyata yang dapat diukur yang berupa pengetahuan, sikap dan ketrampilan sebagai interaksi aktif antara subyek belajar dengan obyek belajar selama berlangsungnya proses belajar mengajar. Motivasi berkaitan erat dengan prestasi hasil belajar siswa. Bila siswa punya motivasi yang tinggi dalam belajar maka prestasi belajarnya akan meningkat. Sebaliknya bila siswa tidak ada motivasi belajar, dengan sendirinya hasil prestasi belajarnya akan rendah.

Pada pembelajaran Sejarah, motivasi siswa untuk belajar masih rendah. Ini dibuktikan ketika mereka diberi pertanyaan di awal pelajaran banyak yang tidak menjawab, disaat dijelaskan materi banyak yang tidak memperhatikan bahkan berbicara sendiri. Keadaan ini tentu membuat prihatin sehingga perlu mencari jalan pemecahannya agar tidak berlarut-larut yang nantinya bisa mempengaruhi prestasi belajar siswa.

Sebagai solusi dalam pembelajaran Sejarah dapat diterapkan metode Cerita Bergambar. Cerita Bergambar atau ilustrasi dalam bahasa Ingrris disebut Illustration, dalam bahasa Latin illustrare yang berarti menjelaskan atau menerangkan sesuatu. Dalam seni rupa ilustrasi dipergunakan untuk memperjelas suatu cerita atau artikel dengan gambar - gambar. Gambar-gambar itu selain mempunyai daya tarik juga harus jelas, sederhana, mudah dimengerti dan mewakili isi cerita yang terkandung didalamnya. Untuk itulah dalam proses pembuatannya perlu adanya penghayatan atau penjiwaan isi dari cerita atau karangan tersebut. Cerita bergambar biasanya menggambarkan isi karya tulisan seperti novel, komik, dsb.Bentuk hiasan yang digunakan antara lain gambar, foto, kartun, karikatur dan vinyet. Dalam cerita bergambar ini unsur gambar sangat dominan, kata-kata hanya dipergunakan untuk keterangan gambar yang dimaksud. Jenis ilustrasi ini banyak kita jumpai pada majalah anak-anak, koran atau komik-komik.jenis cerita yang ditampilkan antara lain cerita silat, cerita pewayangan, cerita legenda, cerita kerajaan, cerita keluarga dan lainnya( Nursantara,Yayat,2007:6 )

Penelitian ini bertujuan untuk mengetahui hasil belajar Sejarah siswa dengan menggunakan metode Cerita Bergambar.

\section{METODE \\ Pendekatan dan Jenis penelitian}

Pendekatan yang digunakan dalam penelitian ini adalah pendekatan kualitatif. Jenis penelitiana adalah penelitian tindakan kelas. Penelitian dirancang dalam bentuk siklus tindakan yang terdiri dari empat kegiatan yaitu rencana tindakan, pelaksanaan, pengamatan dan refleksi.

\section{Lokasi dan Subyek Penelitian}

Penelitian dilaksanakan di SMA Negeri 1 Blitar kelas XI MIPA 8. Subyek penelitian adalah seluruh siswa sebanyak 33 siswa. 


\section{Instrumen Penelitian}

Instrumen yang digunakan untuk memperoleh data penelitian adalah naskah tes hasil belajar berupa lembar soal essay dan lembar observasi atau pengamatan terhadap peserta didik selama mengikuti pembelajaran.

\section{Teknik pengumpulan dan analisis data.}

Data yang dikumpulkan adalah melalui catatan observasi dan hasil evaluasi yang dilakukan sejak awal hingga sampai siklus 3. Catatan observasi digunakan untuk mengetahui motivasi siswa dalam penguasaan materi baik dalam bentuk gambar maupun penjelasan diskusi, keaktifan siswa selama KBM berlangsung. Sedang evaluasi digunakan untuk mengukur peningkatan prestasi belajar siswa. Indikator keberhasilan dari penelitian ini adalah minimal 85 persen peserta didik mencapai skor tes hasil belajar minimal 75 .

Data hasil observasi pembelajaran dianalisis kemudian ditafsirkan berdasar kajian pustaka dan pengalaman guru, sedangkan hasil belajar siswa dianalisis berdasarkan evaluasi hasil belajar dari siklus 1, 2, dan 3 .

\section{HASIL \\ Siklus 1 \\ Perencanaan tindakan}

Pada siklus ini rencana tindakan dilakukan selama 2 pertemuan dengan alokasi waktu 2 x 45 menit setiap pertemuan. Persiapan yang dilakukan sebelum melaksanakan tindakan yaitu : menyusun RPP yang sesuai dengan silabus yang telah dibuat guru. menyiapkan instrumen observasi, instrumen evaluasi dan membuat dokumen berupa foto

\section{Pelaksanaan tindakan}

Pelaksanaan tindakan pada siklus 1 diawali dengan penjelasan guru secara umum tentang materi yang sesuai dengan metode cerita bergambar yaitu Perlawanan di berbagai daerah di Indonesia dalam menentang dominasi bangsa asing. Siswa dibagi menjadi lima kelompok dengan masing-masing kelompok satu tema. Masingmasing kelompok kemudian mempresentasikan cerita bergambar. Selama pembelajaran berlangsung, guru mengamati tingkat partisipasi siswa dalam kegiatan tersebut.

Pengamatan dilakukan dengan mengamati perilaku siswa terhadap penggunaan metode cerita bergambar, memantau jalannya presentasi atau kerjasama antar kelompok, mengamati cara siswa menjelaskan dan memberi tanggapan dalam presentasi diperoleh hasil sebagai berikut.

Dalam membuat cerita bergambar baru dijumpai 2 kelompok yang sudah selesai menggambar, 2 kelompok masih setengah jadi dan 1 kelompok masih bingung karena dalam kelompok tersebut banyak anggotanya yang tidak bisa menggambar.

Dalam mempresentasikan hasil cerita bergambar dijumpai 2 kelompok yang sudah lancar, 2 kelompok kurang menguasai materi dan 1 kelompok belum bisa menjelaskan dengan sungguh-sungguh karena gambar - gambar belum jadi sepenuhnya. Keaktifan siswa dalam bertanya dan memberi masukan masih 2 kelompok ( $40 \%$ ). Dari hasil ulngan harian pada materi ini ada 20 dari 33 anak yang nilainya diatas KKM atau tuntas ( $60 \%$ )

\section{Siklus 2}

\section{Perencanaan}

Dilakukan dengan menyusun rencana perbaikan, memadukan hasil refleksi siklus 1 agar siklus 2 lebih efektif. Menyiapkan instrumen observasi, angket dan evaluasi. 


\section{Pelaksanaan}

Pada pelaksanaan siklus kedua ini guru memberikan hasil KBM dan informasi hasil siklus 1 . Kelompok yang belum aktif dalam presentasi untuk maju mengulangi presentasi. Guru tetap mengamati tingkat partisipasi siswa selama kegiatan pembelajaran.

\section{Pengamatan}

Setelah melaksanakan tindakan pada siklus kedua, diperoleh hasil sebagai berikut. Dalam membuat cerita bergambar sudah dijumpai 3 kelompok dengan gambar bagus dan 2 kelompok dengan gambar setengah jadi. Dalam mempresentasikan hasil cerita gambar dijumpai 3 kelompok yang bagus, 1 kelompok yang sedang dan 1 kelompok yang kurang dalam menjelaskan cerita bergambar. Keaktifan peserta dalam bertanya mulai meningkat $73 \%$. Dari hasil ulangan harian, 26 dari 33 anak mendapat nilai diatas KKM ( $78 \%$ ).

\section{Siklus 3}

Perencanaan

Siswa menerima penjelasan mengenai kegiatan yang akan diikutinya yaitu dengan menggunakan metode cerita bergambar yang sudah disusun berdasarkan perbaikan- perbaikan pada siklus kedua.

\section{Pelaksanaan}

Pada tahap pelaksanaan siklus ketiga ini, guru menjelaskan hasil KBM dan informasi hasil siklus kedua dengan cara : meminta kelompok yang belum berhasil menjelaskan gambar untuk mengulangi tampil presentasi. Guru tetap mengadakan pengamatan terhadap tingkat partisipasi siswa dalam kegiatan pembelajaran.

\section{Pengamatan}

Setelah melaksanakan tindakan pada siklus ketiga diperoleh hasil sebagai berikut. Dalam membuat cerita bergambar sudah dijumpai 4 kelompok dengan gambar sangat bagus dan 1 kelompok bagus. Semua kelompok berani dan bagus dalam menjelaskan cerita bergambar. Sudah ada pemerataan menjawab dan memberikan tanggapan. Keaktifan bertanya sudah meningkat $90 \%$. Dari hasil ulngan harian 31 dari 33 siswa yang mendapat nilai diatas KKM (93\%)

\section{PEMBAHASAN Siklus 1}

Dari hasil pengamatan pada siklus 1 sebagian besar siswa tertarik, namun ada beberapa hal yang perlu diperbaiki antara lain : untuk kelompok yang belum jadi dalam pembuatan cerita bergambar, perlu diberi motivasi agar perkembangan pemikirannya meningkat, untuk yang masih ragu-ragu dalam mempresentasikan diharapkan mempelajari lebih banyak materi.

\section{Siklus 2}

Dari hasil pengamatan yang dilakukan pada siklus kedua sebagian besar siswa sudah termotivasi untuk belajar sejarah. Namun masih ada beberapa hal yang perlu diperbaiki antara lain : untuk 1 kelompok dengan gambar setengah jadi perlu diberi motivasi tersendiri agar gambar yang dibuat segera selesai dan siap untuk dipresentasikan. Bagi siswa yang belum aktif dalam memberikan pertanyaan atau tanggapan perlu dimotivasi lagi. Bagi siswa yang nilai ulangan hariannya dibawah ketuntasan belajar diberikan motivasi dan pendekatan yang baik dari guru. 


\section{Siklus 3}

Pada akhir siklus ketiga, hasil pembelajaran sudah memenuhi harapan. Motivasi anak dalam belajar sejarah meningkat, keberanian siswa dalam menjelaskan dan mengemukakan pendapat bertambah baik. Perhatian siswa dalam menyimak pelajaran membaik dibuktikan dengan keaktifan bertanya dan mencatat pertanyaan atau jawaban, hasil prestasi belajar siswa juga meningkat.

Dari hasil penelitian menunjukkan bahwa kemampuan siswa dalam memahami dan menguasai materi dengan metode Cerita Bergambar sangat memuaskan. Secara keseluruhan hasilnya menunjukkan adanya peningkatan dalam motivasi belajar, keberanian berbicara dan mengemukakan pendapat di depan kelas, keaktifan bertanya, keaktifan mencatat materi diskusi dan yang terpenting adalah peningkatan prestasi belajar.

Dari hasil observasi dapat dilihat bahwa motivasi belajar siswa ternyata sangat menentukan prestasi belajarnya sehingga dengan motivasi belajar yang tinggi siswa dapat mencapai hasil belajar sesuai yang diharapkan.

\section{KESIMPULAN}

Berdasarkan hasil Penelitian Tindakan Kelas diatas dapat disimpulkan bahwa: (1) dengan metode Cerita Bergambar, motivasi belajar siswa meningkat karena timbul keinginan untuk menguasai materi dengan baik, menuangkan dan memahami materi dalam wujud gambar, menjelaskan materi dalam gambar dan menjawab pertanyaan dalam gambar; (2) prestasi belajar sejarah pada materi Perlawanan di berbagai Daerah di Indonesia dalam Menentang Dominasi Bangsa Asing dengan metode Cerita Bergambar mengalami peningkatan yang signifikan.

\section{SARAN}

Dari hasil simpulan diatas, dapat disarankan hal - hal sebagai berikut: (1) perlu memberi motivasi belajar siswa dengan menggunakan berbagai metode pembelajaran salah satunya Cerita Bergamabar untuk meningkatkan hasil prestasi belajar siswa; (2) perlu dikembangkan metode-metode yang variatif sesuai dengan kompetensi dasar dalam pelajaran Sejarah agar bisa memotivasi dan meningkatkan kreativitas siswa dan guru; (3) guru harus bisa menjadi fasilitator yang baik bagi siswa sehingga mereka dapat lebih kreatif dan berprestasi.

\section{DAFTAR RUJUKAN}

Asrori, H, Mohammad. 2007. Psikologi Pembelajaran. Bandung: Wacana Prima. Nursantara, Yayat. 2007. Seni Budaya Untuk SMA Kelas X. Jakarta: Erlangga. Rasyid, Harun dkk. 2008. Penilaian hasil Belajar. Bandung : Wacana Prima.

Slavin, Robert E. 2005. Cooperative Learning Teori, Riset dan Praktik, Terjemahan Narulita Yusron. Bandung: Nusa Media

Sukidin, dkk. 2008. Manajemen Penelitian Tindakan Kelas. Jakarta : Insan Cendekia.

Sukmadinata, Nana Syaodih. 2004. Kurikulum dan Pembelajaran Kompetensi. Bandung: Yayasan Kusumakarya

Sumiati, dkk. 2007. Metode pembelajaran. Bandung : Wacana Prima.

Susilana, Rudi. 2007. Media pembelajaran: Hakikat, Pengembangan, Pemanfaatan dan Penilaian. Bandung: Wacana Prima. 